\title{
Motivasi Belajar dan Berprestasi Mahasiswa Bidikmisi di Institut Agama Islam Negeri Padangsidimpuan
}

\author{
Mustamin Siregar \\ Pondok Pesantren Jabalul Madaniyah Sijungkang Tapanuli Selatan \\ mustaminsiregar29@gmail.com
}

\begin{abstract}
Abstrak
The article aims to explain the motivation to learn and achievers students in academic year 2015-2016 at the Institute of Islamic Religion of Padangsidimpuan State which is seen from the student's efforts to obtain a mission scholarship. This research uses a qualitative approach with constant comparison analysis. The results of the study indicated that the students who obtained the academic year scholarship 2015-2016 at the Institute of Islamic Religious Affairs, Padangsidimpuan, had motivation to learn which was stimulated by the desire and desire, there was encouragement and Needs in learning, and future expectations and ideals
\end{abstract}

Keywords: motivation; learning; achievement; mission

\begin{abstract}
Abstrak
Atikel ini bertujuan untuk menjelaskan motivasi belajar dan berprestasi mahasiswa bidikmisi tahun akademik 2015-2016 di Institut Agama Islam Negeri Padangsidimpuan yang terlihat dari upaya mahasiswa untuk memperoleh beasiswa bidikmisi. Penelitian ini menggunakan pendekatan kualitatif dengan analisis komparasi konstan. Hasil penelitian menunjukkan bahwa mahasiswa yang memperoleh beasiswa bidikmisi tahun akademik 2015-2016 di Institut Agama Islam Negeri Padangsidimpuan memiliki motivasi belajar yang distimulasi oleh hasrat dan keinginan berhasil, adanya dorongan dan kebutuhan dalam belajar, serta adanya harapan dan cita-cita masa depan.
\end{abstract}

Kata Kunci: motivasi; belajar; prestasi; bidikmisi. 


\section{Mustamin Siregar}

\section{PENDAHULUAN}

Pendidikan bertujuan untuk mengembangkan potensi peserta didik agar menjadi manusia yang beriman dan bertaqwa kepada Allah swt, berakhlak mulia, berilmu, sehat, mandiri, kreatif dan menjadi warga yang demokratis serta betanggung jawab. ${ }^{1}$ Pendidikan merupakan kebutuhan yang sangat penting dalam meningkatkan kualitas sumber daya manusia. Usaha tersebut dilakukan dalam bentuk pembelajaran, pendidik melayani peserta didik melakukan kegiatan belajar. Pendidikan adalah bimbingan secara sadar oleh pendidik terhadap perkembangan jasmani dan rohani peserta didik menuju terbentuknya kepribadian yang utama. ${ }^{2}$ Selama kegiatan belajar motivasi sangat dibutuhkan untuk mendorong siswa atau mahasiswa dalam mengikuti proses belajar di dalam kelas. ${ }^{3}$

Dalam proses pembelajaran kebutuhan tersebut berhubungan dengan kebutuhan untuk belajar. Teori behaviorisme menjelaskan bahwa motivasi berfungsi sebagai rangsangan (stimulus) dan respons. Sedangkan teori kognitif, menjelaskan bahwa motivasi berfungsi sebagai dinamika psikologis yang lebih rumit yaitu melibatkan kerangka berpikir peserta didik terhadap berbagai aspek tingkah laku. ${ }^{4}$

Motivasi adalah perubahan energi dalam diri seseorang yang ditandai dengan timbulnya perasaan dan reaksi untuk mencapai tujuan. Dalam proses pembelajaran motivasi dianggap penting karena dengan motivasi tidak akan ada suatu perubahan dalam diri seseorang dan tidak akan timbul suatu perbuatan misalnya belajar. ${ }^{5}$

Bidikmisi adalah bantuan biaya pendidikan yang diberikan pada mahasiswa baru yang tidak mampu secara ekonomi dan berpotensi akademik baik. Proses perekrutan bidikmisi dimulai sebelum pendaftaran seleksi masuk perguruan tinggi Negeri.

${ }^{1}$ Undang-Undang Republik Indonesia Nomor 20 Tahun 2003 Tentang Sistem Pendidikan Nasional (Jakarta: PT. Sinar Grafika, 2006), HIm. 5.

${ }^{2}$ Ahmad Tafsir, Ilmu Pendidikan Dalam Perspektif Islam (Bandung: Remaja Rosdakarya, 2010), HIm. 24.

${ }^{3}$ Hamzah, Teori Motivasi Dan Penerapannya (Jakarta: Buma Aksara, 2014), HIm. 1.

${ }^{4}$ Muhibbin Syah, Psikologi Pendidikan Dengan Pendekatan Baru (Bandung: Remaja Rosdakarya, 2014), HIm. 34.

5 “Hamzah, Teori Motivasi Dan Penerapannya ..., HIm. 23., 
Untuk meningkatkan motivasi belajar mahasiswa, pemerintah secara umum menyediakan program bidikmisi bagi mahasiswa yang menghadapi kendala ekonomi khususnya, tapi tidak terlepas juga dari prestasi akademik yang bagus. Hal ini dibuktikan dengan nilai-nilai yang mereka peroleh pada saat mendaftar kuliah dan pada saat akhir semester perkuliahan. Dengan program bidikmisi diharapkan dapat mencetak lulusan yang produktif, mandiri dan memiliki kepedulian sosial yang berperan dalam upaya pemberdayaan masyarakat dan pemutusan mata rantai kemiskinan.

Bantuan biaya pendidikan diberikan mulai sejak calon mahasiswa dinyatakan diterima di perguruan tinggi selama 8 (delapan) semester pada program Strata 1 (S-1) dan 6 (enam) semester untuk program Diploma III (DIII). Beasiswa tersebut berupa pembebasan mahasiswa dari seluruh biaya pendidikan selama berada di perguruan tinggi. Kemudian, mahasiswa penerima Beasiswa Bidikmisi juga mendapat uang saku untuk biaya kuliahnya yang akan diterimanya setiap 3 (tiga) bulan sekali.

Mahasiswa dalam memasuki perguruan tinggi, masing-masing memiliki latar belakang yang berbeda-beda. Ada sebagian dari mahasiswa itu memasuki perguruan tinggi dikarenakan adanya minat, motivasi belajar yang kuat, dan prestasi yang tinggi serta didukung dengan ekonomi yang cukup, sebagiannya juga ada yang hanya dikarenakan motivasi belajar dan perolehan prestasi yang tinggi ketika pendidikan ditingkat SLTA, meskipun dengan keadaan ekonomi yang kurang mencukupi.

Institut Agama Islam Negeri Padangsidimpuan adalah salah satu perguruan tinggi Negeri yang berdomisili di daerah Tapanuli Bagian Selatan. Disetiap tahun ajaran barunya, perguruan tinggi ini selalu menyalurkan dana berupa bantuan kepada mahasiswa yang mempunyai semangat dan memiliki minat dan motivasi belajar yang tinggi. Bantuan ini tidak hanya tertuju kepada peserta didik yang berprestasi saja, akan tetapi juga tertuju kepada peserta didik yang kurang mampu untuk melanjutkan pendidikan. Dengan demikian, pihak civitas akademik Institut Agama Islam Negeri Padangsidimpuan pun dalam menyeleksinya sesuai dengan prosedur penerimaannya. 


\section{Mustamin Siregar}

Tahun akademik 2015-2016, mahasiswa yang mendapatkan beasiswa bidikmisi pada tahun akademik ini berjumlah 100 mahasiswa, yang terdiri 10 orang dari Fakultas Syariah dan IImu Hukum, 33 orang dari Fakultas Tarbiyah dan IImu Keguruan, 10 orang dari Fakultas Dakwah dan Ilmu Komunikasi, dan 47 orang dari Fakultas Ekonomi dan Bisnis Islam. IPK tertinggi sebesar 3,78 diperoleh oleh Mirnawati Sihotang mahasiswa jurusan Hukum Ekonomi Syariyah dan IPK terendah sebesar 2,73 diperoleh oleh Yogi Riski Pratama mahasiswa jurusan Tadris Matematika.

Hasil wawancara peneliti menunjukkan bahwa pada umumnya mahasiswa yang memperoleh beasiswa bidikmisi diambil berdasarkan prestasi yang diperoleh di setiap Fakultas masing-masing seperti mahasiwa yang bernama Alwi Akbar Ginting yang memperoleh prestasi nilai IPK 3,76 dan mampu meraih prestasi pada kegiatan formal seperti lomba sidang semu, dan debat Nasional NEDC.

Dari temuan awal menunjukkan bahwa IPK mahasiswa bidikmisi di atas 3,00 berjumlah sebanyak 95 orang mahasiswa atau sebesar $95 \%$, dan di bawah 3,00 ada berjumlah 5 orang mahasiswa atau sebesar $5 \%$. Berdasarkan temuan tersebut dapat dilihat bahwasanya mahasiswa bidikmisi mampu mempertahankan prestasinya mulai dari jenjang pendidikan SLTA sampai pendidikan di perguruan tinggi.

Hasil wawancara dengan salah satu mahasiswa penerima beasiswa bidikmisi mengungkapkan bahwasanya pada tahap awal pengajuan penerima beasiswa bidikmisi tersebut harus mengisi semua data-data yang terlampir diformat pengajuan tersebut, seperti perolehan nilai, keadaan keluarga, dan jenis pekerjaan dari orangtau peserta didik yang mengajukan. Lebih lanjut, saudara Munawirul Umam mengatakan bahwasanya tidak semua peserta didik yang berprestasi itu dinyatakan lulus dalam pengajuan beasiswa bidikmisi tersebut.

Sesuai dengan temuan peneliti di atas, bahwa mahasiswa yang memperoleh bantuan biaya pendidikan bidikmisi dilatar belakangi dengan prestasi yang tinggi, dengan cara menyeleksi tiap-tiap lembaga pendidikan formal jenjang pendidikan SLTA. Dengan demikian, setiap mahasiwa yang memperoleh beasiswa bidikmisi harus meningkatkan prestasi yang diperolehnya itu. Tapi sesuai dengan realita yang diperoleh peneliti bahwa tidak semua mahasiswa 
beasiswa bidikmisi itu mampu meningkatkan prestasinya itu, hanya hitungan beberapa orang saja yang mampu meningkatkan hingga dapat memperoleh nilai Cumlaude yaitu hanya $3 \%$, dan yang lainnya hanya mampu memperoleh nilai sangat memuaskan $27 \%$, memuaskan $69 \%$, dan cukup $1 \%$.

Uno menyatakan bahwa motivasi dan belajar merupakan dua hal yang saling mempengaruhi. ${ }^{6}$ Motivasi berasal dari bahasa latin yaitu "movere", artinya "bergerak". Movere maksudnya adalah mendorong dengan arti menuntun tingkah laku seseorang. Kata motivasi berasal dari motif yang berati daya penggerak yang timbul dalam diri seseorang untuk melakukan suatu pekerjaan ataupun aktivitas. ${ }^{7}$

Berdasarkan pengertian motivasi di atas, dapat disimpulkan bahwa motivasi adalah segala sesuatu yang menggerakkan atau yang mendorong seseorang untuk melakukan sesuatu untuk mencapai tujuan tertentu. Sedangkan belajar menurut Slameto ialah suatu proses usaha yang dilakukan seseorang untuk memperoleh suatu perubahan tingkah laku yang baru secara keseluruhan, sebagai hasil pengalamannya sendiri dalam interaksi dengan lingkungannya. ${ }^{8}$

Motivasi belajar adalah perubahan energi dalam diri (pribadi) seseorang yang ditandai dengan timbulnya perasaan dan reaksi untuk mencapai tujuan. ${ }^{9}$ Adapun ciri-ciri dari motivasi belajar yang ada pada peserta didik yaitu, sebagai berikut: tekun dalam mengerjakan segala tugas, Ulet dalam menghadapi kesulitan dan tidak langsung putus asa, menunjukkan minat terhadap berbagai persoalan, pekerjaan dilakukan dengan mandiri, konsisten dan berpegang teguh pada pendapat, tidak mudah melepaskan dan gemar memacahkan masalah dan bahkan mencari masalah. ${ }^{10}$

Adapun macam-macam motivasi yaitu motivasi Intrinsik dan ekstrinsik. Adapun fungsi motivasi belajar dalam pembelajaran, yaitu mendorong timbulnya suatu perbuatan, motivasi berfungsi sebagai pengarah, dan motivasi berfungsi sebagai penggerak.

\footnotetext{
${ }^{6}$ Hamzah B. Uno, Teori Motivasi dan Pengukurannya (Jakarta: Bumi Aksara, 2009), hlm. 23.

${ }^{7}$ Iskandar, Psikologi Pendidikan Sebuah Orientasi Baru (Jakarta: Referensi. 2012), HIm.180.

${ }^{8}$ Slameto, Belajar Dan Faktor-Faktor Yang Mempengaruhinya (Jakarta: Rineka Cipta, 2013), HIm. 2.

${ }^{9}$ Oemar Hamalik, Proses Belajar Mengajar (Jakarta: Bumi Aksara.2013), HIm. 158.

${ }^{10}$ Sardiman, Interaksi Dan Motivasi Belajar Mengajar (Jakarta: Raja Grafindo Persada.2007), HIm.
} 83. 


\section{Mustamin Siregar}

Motivasi berprestasi adalah suatu kebutuhan yang mendorong individu dalam mencapai suatu keberhasilan dengan mempertimbangkan standar yang mesti dicapai. Keberhasilan yang mesti dicapai di antaranya bersifat intrinsik maupun ekstrinsik yang bertujuan untuk memperoleh nilai kesuksesan. Seseorang yang mempunyai motivasi berprestasi tinggi akan mempunyai performance yang lebih bagus jika dibandingkan dengan orang yang memiliki motivasi berprestasi rendah. ${ }^{11}$

Beasiswa pendidikan bagi mahasiswa miskin berprestasi atau yang sering dikenal dengan sebutan Bidikmisi. Oleh karena itu, tidak sembarang mahasiswa yang bisa mendapatkan beasiswa tersebut. Hanya mahasiswa tertentu saja yang dinyatakan memenuhi persyaratan dan kriteria yang telah ditetapkan langsung oleh Kementrian Riset Teknologi dan Pendidikan Tinggi sebagai mahasiswa yang berhak dan layak menerima Bidikmisi. ${ }^{12}$

Pada program ini, bantuan yang diberikan terdiri dari bantuan biaya hidup yang diberikan kepada mahasiswa sekurang-kurangnya $\mathrm{Rp}$ 600.000,-(enam ratus ribu rupiah) perbulan yang ditentukan berdasarkan Indeks Harga Kemahalan daerah lokasi PTN dan bantuan biaya penyelenggaraan pendidikan yang dikelola PTN sebanyak 23 banyaknya Rp 2.400.000,- (dua juta empat ratus ribu rupiah) persemester permahasiswa. ${ }^{13}$

\section{METODE PENELITIAN}

Jenis penelitian ini dengan menggunakan metode kualitatif dan pendekatan naturalistik. Kualitatif yaitu mendeskripsikan peristiwa yang terjadi dilapangan penelitian. Dalam penelitian in, penulis mendeskripsikan motivasi belajar dan berprestasi Mahasiswa Bidikmisi di Institut Agama Islam Negeri Padangsidimpuan.

\section{HASIL DAN PEMBAHASAN}

IAIN Padangsidimpuan didirikan untuk membentuk Sarjana yang beriman dan bertakwa serta berakhlak mulai, cakap, dan terampil dalam kajian-kajian

\footnotetext{
${ }^{11}$ Bimo Walgito, Pengantar Psikologi Umum (Yogyakarta: Andi, 2010), HIm. 57.

${ }^{12}$ Ristekdikti, Pedoman Bidik Misi Tahun 2017 (Jakarta: Ristekdikti, 2017), HIm. 3.
} 
keislaman serta mempunyai tanggungjawab yang tinggi bagi keselamatan dan kemaslahatan umat, bangsa,dan negara Republik Indonesia yang berdasarkan Pancasila dan Undang-undang Dasar 1945. IAIN Padangsidimpuan dewasa ini memiliki empat Fakultas, mengasuh 18 Jurusan, dan 1 Pascasarjana. Fakultas yang dimaksudkan adalah Fakultas Syari'ah dan IImu Hukum (FASIH) terdapat Jurusan Ahwal Al-Syakhsiyah (AS), Jurusan Hukum Ekonomi Syari'ah (HES), Jurusan Hukum Tata Negara (HTN), Jurusan Ilmu Al-Qur'an dan Tafsir (IAT), Jurusan Hukum Pidana Islam (HPI). Begitu juga dengan Fakultas Tarbiyah dan IImu Keguruan (FTIK) terdapat: Jurusan Pendidikan Agama Islam (PAI), Jurusan Tadris/Pendidikan Matematika, Jurusan Tadris/Pendidikan Bahasa Inggris, Jurusan Pendidikan Bahasa Arab, Jurusan Pendidikan Guru Raudlatul Athfal dan Jurusan Pendidikan Guru Madrasah Ibtidaiyah (PGMI). Kemudian, Fakultas Dakwah dan IImu Komunikasi (FDIK) terdapat Jurusan Komunikasi dan Penyiaran Islam (KPI), Jurusan Bimbingan Konseling Islam (BKI), Jurusan Manajemen Dakwah (MD), dan Jurusan Pengembangan Masyarakat Islam (PMI). Begitujuga dengan Fakultas Ekonomi dan Bisnis Islam (FEBI) terdapat Jurusan Perbankan Syari'ah (PS), Jurusan Ekonomi Syari'ah (ES), Jurusan Manajemen Zakat dan Wakaf $(M Z W)$. Tidak asing lagi dengan Pascasarjana Program Magister yaitu Program Magister Pendidikan Agama Islam.

Selain melaksanakan pendidikan dan pengajaran, IAIN Padangsidimpuan juga berkonsentrasi dalam pengembangan bahasa Arab dan Inggris melalui kegiatan program intensifikasi bahasa dan program asrama. Dengan demikian, lulusan/alumninya diharapkan dapat menggunakan bahasa Arab dan Inggris secara aktif, lisan dan tulisan dan dapat bersaing dalam era global.

Perguruan tinggi merupakan suatu jenjang pendidikan yang dapat dijalani seseorang setelah menyelesaikan pendidikannya di jenjang pendidikan menengah atas. Dengan menempuh pendidikan di perguruan tinggi, maka mahasiswa bisa mendapatkan tambahan ilmu serta keterampilan yang dapat digunakan di kehidupan serta untuk mempersiapkan masa depannya. Selain itu, dengan menempuh pendidikan di perguruan tinggi mahasiswa bisa mendapatkan suatu gelar yaitu gelar sarjana. Dalam penulisan skripsi, mahasiswa dituntut untuk mampu berpikir secara induktif dan deduktif. 


\section{Mustamin Siregar}

Proses pendidikan yang dilalui oleh mahasiswa di setiap perguruan tinggi, banyak tantangan dan rintangan yang harus mereka hadapi, sehingga setiap mahasiswa yang hendak menyelesaikan pendidikan di perguruan tinggi harus mempersiapkan modal yang cukup untuk menutupi biaya-biaya yang diperlukan.

Namun, realitanya tidak semua mahasiswa tergolong dari keluarga yang punya atau memiliki biaya yang mencukupi. Namun dengan adanya bantuan dari pemerintah, banyak mahasiswa berlomba-lomba untuk dapat memperoleh bantuan tersebut, yaitu yang disebut dengan bantuan biaya pendidikan, salah satunya adalah bantuan biaya pendidikan bidikmisi.

Syarat utama yang harus disiapkan oleh mahasiswa untuk memperoleh bantuan biaya pendidikan ini adalah nilai belajar yang maksimal ketika di SLTA, sehingga pada waktu seleksi mahasiswa penerima bantuan ini harus menunjukkan nilai raport yang diperoleh dari waku kelas $X$ semester 1 sampai kelas XII semester 2.

Di Institut Agama Islam Negeri Padangsidimpuan mahasiswa memperoleh bantuan biaya pendidikan bidikmisi itu tidak hanya didasarkan kepada kriteriakriteria nilai yang tinggi, tetapi juga kriteria kurang mampu untuk membutuhi biaya pendidikan. Hal yang demikian, karena pada proses seleksi penerimaan bantuan biaya pendidikan atau bidikmisi, mahasiswa harus melampirkan dokumentasi yang terdiri dari dokumen surat keterangan kurang mampu dan foto rumah tempat tinggal mahasiswa tersebut.

Penulis melihat bahwa salah satu pendorong banyaknya dari kalangan masyarakat ekonomi menengah ke bawah yang berminat untuk memasuki perguruan tinggi ini adalah karena adanya beasiswa, diantaranya program biaya pendidikan bidikmisi yang diluncurkan oleh pemerintah secara langsung dan diberikan kepada mahasiswa yang sudah memenuhi persyaratan. Motivasi belajar mahasiswa bidikmisi tahun akademik 2015-2016 di Institut Agama Islam Negeri Padangsidimpuan dapat diuraikan sebagai berikut:

a. Adanya hasrat dan keinginan untuk menjadi sarjana

Faktor pendorongnya dilatar belakangi oleh berbagai fakultas dan jurusan yang ada di perguruan tinggi ini. Berdasarkan hasil wawancara penulis, 
bahwasanya mahasiswa banyak meminati perguruan tinggi ini tidak hanya didasari oleh kelengkapan fakultas dan jurusan yang ada di perguruan tinggi ini.

b. Adanya dorongan untuk belajar

Institut Agama Islam Negeri Padangsidimpuan adalah perguruan tinggi Islam negeri yang dilengkapi dengan berbagai program-program yang dapat membangkitkan semangat belajar mahasiswa. Oleh karena, mahasiswa yang masuk lewat seleksi penerimaan mahasiswa bidikmisi di perguruan tinggi ini lebih memiliki motivasi belajar yang tinggi, karena adanya yang diharapkan untuk dapat memenuhi kebutuhan belajar, yakni dengan adanya program beasiswa ini, meskipun mahasiswa mengambil jurusan matematika ataupun bahasa inggris, di perguruan tinggi Islam initetap memperoleh pendidikan agama juga. Seperti pemahaman IImu Tauhid, IImu Tasawuf, Ulumul Qur'an, Ulumul Haidts, dan lain sebagainya.

C. Adanya cita-cita di masa depan

Keterampilan dan kedisiplinan itu tidak muncul dengan begitu saja, melainkan karena adanya harapan dan cita-cita masa depan. Untuk dapat meraih harapan dan cita-cita masa depan itu, mahasiswa harus berusaha semaksimal mungkin. .

Mahasiswa yang mampu disiplin dan aktif dalam melaksanakan kegiatan di perguruan tinggi, seperti mahasiswa yang mengambil jurusan keguruaan, pastinya berharap menjadi seorang guru yang professional, dan mahasiswa yang mengambil jurusan dibidang hukum berharap mampu menjadi seorang pengacara atau advokat yang bermutu.

Penulis menyimpulkan bahwasanya mahasiswa yang memperoleh beasiswa bidikmisi di Institut Agama Islam Negeri Padangsidimpuan memiliki motivasi belajar yang tinggi, karena adaya hasrat dan keinginan berhasil, adanya harapan dan cita-cita masa depan, serta karena adanya dorongan dan kebutuhan dalam belajar, yakni kebutuhan belajar yang meliputi ilmu-ilmu agama dan sains. Mahasiswa yang memperoleh beasiswa bidikmisi di perguruan tinggi ini dilatar belakangi oleh beberapa faktor, yaitu meliputi tingkat kebutuhan belajar dan minat belajar yang tinggi, sehingga mereka berupaya semaksimal mungkin untuk bisa memperoleh beasiswa bidikmisi tersebut. Untuk lebih jelasnya berikut uraiannya: 


\section{Mustamin Siregar}

a. Faktor kebutuhan belajar

Sebagian dari mahasiswa ada yang tergolong dari keluarga yang paspasan, bahkan kurang dalam membutuhi biaya hidup. Namun karena adanya program beasiswa bidikmisi ini, sehingga mahasiswa lebih semangat dalam belajar dan berupaya semaksimal mungkin untuk dapat memperoleh biaya bantuan pendidikan tersebut. 14

Salah satu mahasiswa yang tergolong dari keluarga yang kurang mampu, yakni keluarga petani dan ayahnya sudah meninggal dunia ketika ia masih duduk di bangku SD. Salah satu faktor yang bisa menentukan motivasi belajarnya adalah tingkat kebutuhan belajar yang kurang mencukupi, karena ia merasa jika tidak mampu bersaing dengan banyaknya mahasiswa yang ingin memperoleh beasiswa bidikmisi tersebut

b. Faktor minat belajar

Keluarga mahasiswa yang tergolong sebagai keluarga yang pas-pasan, karena mata pencaharian orangtua hanya petani.

Dari beberapa ungkapan di atas, penulis menyimpulkan bahwa faktor-faktor yang menentukan motivasi belajar mahasiswa bidikmisi tahun akademik 2015/2016 di Institut Agama Islam Negeri Padangsidimpuan meliputi kepada faktor tingkat kebutuhan belajar dan minat belajar mahasiwa. Berikut ini penjelasan lebih rinci tentang motivasi berprestasi mahasiswa bidikmisi tanun akademik 2015-2016 di Institut Agama Islam Negeri Padangsidimpuan, yakni: pertama: tuntutan IPK Minimal 3,00 ketika mahasiswa memperoleh bantuan biaya pendidikan di perguruan tinggi ini tidak hanya berdasarkan motivasi belajar saja, akan tetapi juga didasari dengan motivasi berprestasi dengan bukti IPK 3,00. Kedua, Aktif Mengikuti kegiatan-kegiatan forum ilmiah (Pekerja Keras) Keaktifan mahasiswa dalam mengikuti kegiatan forum ilmiah menjadi salah satu penilaian yang tersendiri bagi dosen.

Adapun faktor-faktor yang menentukan motivasi berprestasi mahasiswa bidikmisi tahun akademik 2015-2016 di Institut Agama Islam Negeri Padangsidimpuan yaitu pada kenyataannya ditemukan tuntutan prestasi akademik pada mahasiswa semakin tinggi sementara daya belajarnya biasa-biasa saja.

\footnotetext{
${ }^{14}$ Hasil Observasi di Lingkungan Institut Agama Islam Negeri Padangsidimpuan.
} 
Untuk menentukan motivasi berprestasi mahasiswa bidikmisi tahun akademik 2015-2016 di Institut Agama Islam Negeri Padangsidimpuan sesuai dengan temuan penulis di lapangan yakni meliputi kepada dua hal, yaitu kemampuan mahasiswa dan cita-cita atau aspirasi mahasiswa. Dengan kedua hal ini mampu menjadikan mahasiswa bidikmisi khususnya di perguruan tinggi ini mampu maraih prestasi yang jauh lebih baik dari prestasi ketika pendidikan di jenjang SLTA. Berikut ini penjelasannya lebih lanjut: Kesatu, Faktor kemampuan mahasiswa dimana salah saeorang mahasiswa dikategorikan sebagai mahasiswa bidikmisi yang memiliki motivasi prestasi dengan ketekunannya dalam berkarya dan aktif megikuti program-program non akademik. Kemampuan mahasiswa dalam berkarya merupakan salah satu hal yang sangat urgen untuk dimiliki oleh setiap mahasiswa, karena dengan kemampuan itu akan melahirkan banyak inovasi-inovasi yang berdampak terhadap prestasi. Khususnya bagi mahasiswi jurusan Hukum Ekonomi Syariah yang sering mengikuti lomba karya ilmiah di Fakultas Syariah dan Ilmu Hukum. Banyak bentuk karya ilmiah yang seyogiyanya mampu dikuasai oleh mahasiswa, seperti menyusun opini, jurnal, makalah dan lain sebagainya. Salah seorang mahasiswa yang memiliki kemampuan diberbagi hal dilihat dari banyaknya kegiatan-kegiatan yang diikutinya seperti Debat Nasional NEDC (National Ekonomic Debate Competition) di Universitas Malang 12-13 Mei 2018, lomba Sidang semu Fakultas Syariyah dan IImu Hukum IAIN Padangsidimpuan 11 Desember 2018, dan lain sebagainya. Kedua, Faktor citacita atau aspirasi mahasiwa yang mana Cita-cita atau aspirasi merupakan salah satu faktor yang sangat mendukung motivasi berprestasi mahasiwa, karena mahasiswa banyak yang mengingat kembali waktu proses pendidikan di jenjang pendidikan SLTA yang belum dapat dikatakan berprestasi, namun setelah masuknya di perguruan tinggi ini dan mahasiswa dapat menikmati nyamannya belajar dengan kedewasaan, sehingga tumbuhlah cita-cita yang lebih matang untuk diraih. Oleh karena itu, banya mahasiswa yang bersyukur masuk diperguruan tinggi ini, dilain dari kelengkapan jurusan umum, juga dilengkapi dengan program bantuan biaya pendidikan atau beasiswa bidikmisi, sehingga munculnya persaingan dalam meraih bantuan biaya pendidikan tersebut. 


\section{Mustamin Siregar}

Penelitian yang telah di laksanakan di perguruan tinggi Institut Agama Islam Negeri Padangsidimpuan yang berjudul motivasi belajar dan berprestasi mahaiswa bidikmisi tahun akademik 2015/2016 di Institut Agama Islam Negeri Padangsidimpuan dapat diperoleh hasil bahwasanya motivasi belajar mahasiswa yang tinggi yang dilihat dari segi keaktifan, kedisiplinan, dan keterampilan adalah karena adaya hasrat dan keinginan berhasil, adanya harapan dan cita-cita masa depan, serta karena adanya dorongan dan kebutuhan dalam belajar.

Pada penelitian ini juga penulis menemukan bahwa motivasi berprestasi mahasiswa bidikmisi tahun akademik 2015/2016 yaitu didasari karena perolehan nilai atau IPK di atas 3,00, dan mengikuti kegiatan-kegiatan forum ilmiah, serta kepribadian dari seorang mahasiswa tersebut. Faktor-faktor yang menentukan motivasi berprestasi mahasiswa bidikmisi tahun akademik 2015/2016 di Institut Agama Islam Negeri Padangsidimpuan meliputi kepada dua faktor yaitu kemampuan mahasiswa dan cita-cita atau aspirasi mahasiswa, karena dengan kedua faktor ini memiliki cara yang tersendiri dalam meraih prestasi mereka di perguruan tersebut.

Dengan demikian, hasil analisis penulis dari hasil penelitian merupakan suatu gambaran yang sangat bagus untuk dicontoh bagi mahasiswa lainnya guna untuk dapat meraih motivasi belajar dan prestasi belajar yang lebih baik lagi, karena melihat dari mahasiswa yang mendapatkan bantuan biaya pendidikan ini lebih mampu dalam menempatkan waktunya sehingga waktu-waktu yang mereka miliki ketika berada dilingkungan perguruan tinggi ini dapat memperoleh pembelajaran yang mematangkan cara berfikir mereka.

\section{PENUTUP}

Motivasi belajar mahasiswa bidikmisi tahun akademik 2015-2016 di Institut Agama Islam Negeri Padangsidimpuan distimulasi oleh adanya hasrat dan keinginan berhasil, adanya dorongan dan kebutuhan dalam belajar, serta adanya harapan dan cita-cita masa depan. Faktor-faktor yang menentukan motivasi belajar mahasiswa bidikmisi tahun akademik 2015-2016 di Institut Agama Islam Negeri Padangsidimpuan meliputi kepada faktor tingkat kebutuhan belajar dan minat belajar mahasiwa. Motivasi berprestasi mahasiswa bidikmisi tahun 
akademik 2015-2016 di Institut Agama Islam Negeri Padangsidimpuan yaitu didasari tuntutan perolehan IPK minimal 3,00, dan keaktifan mahasiswa dalam mengikuti kegiatan-kegiatan forum ilmiah, serta kedisiplinan yang melambangkan sebagai kepribadian dari seorang mahasiswa yang berprestasi. Faktor-faktor yang menentukan motivasi berprestasi mahasiswa bidikmisi tahun akademik 2015-2016 di Institut Agama Islam Negeri Padangsidimpuan meliputi kepada dua faktor yaitu kemampuan mahasiswa dan cita-cita atau aspirasi mahasiswa, karena dengan kedua faktor ini mahasiswa terodorong meraih prestasi di perguruan tinggi.

\section{DAFTAR PUSTAKA}

Ahmad Tafsir, IImu Pendidikan Dalam Perspektif Islam, Bandung: Remaja Rosdakarya, 2010.

Bimo Walgito, Pengantar Psikologi Umum, Yogyakarta: Andi, 2010.

Hamzah B. Uno, Teori Motivasi dan Pengukurannya, Jakarta: Bumi Aksara, 2009

Hamzah, Teori Motivasi Dan Penerapannya, Jakarta: Buma Aksara, 2014.

Iskandar, Psikologi Pendidikan Sebuah Orientasi Baru (Jakarta: Referensi. 2012.

Muhibbin Syah, Psikologi Pendidikan Dengan Pendekatan Baru, Bandung: Remaja Rosdakarya, 2014.

Oemar Hamalik, Proses Belajar Mengajar (Jakarta: Bumi Aksara.2013.

Ristekdikti, Pedoman Bidik Misi Tahun 2017, Jakarta: Ristekdikti, 2017.

Sardiman, Interaksi Dan Motivasi Belajar Mengajar, Jakarta: Raja Grafindo Persada. 2007.

Slameto, Belajar Dan Faktor-Faktor Yang Mempengaruhinya, Jakarta: Rineka Cipta, 2013.

Undang-Undang Republik Indonesia Nomor 20 Tahun 2003 Tentang Sistem Pendidikan Nasional, Jakarta: PT. Sinar Grafika, 2006. 